\title{
Hubungan Pengetahuan Ibu Hamil dengan Kecemasan dalam Menghadapi Hiperemesis Gravidarum Kehamilan Trimester I di RSUD Sultan Sulaiman Tahun 2020
}

\author{
Zuidah \\ Program Studi Keperawatan, Universitas Haji Sumatera Utara
}

Info Artikel

Article history:

Diterima 11-06-2021

Revisi 27-06-2021

Disetujui 13-07-2021

\section{Kata kunci:}

Pengetahuan,

Kecemasan,

Hipertensi.

\begin{abstract}
A B S T R A K
Kecemasan pada kehamilan, selain terjadi perubahan fisiologi, psikologis juga memegang peranan yang tidak kalah penting dalam timbulnya mual muntah, Hiperemesis gravidarum yang merupakan komplikasi pada ibu hamil muda bila terjadi terus menerus dapat menyebabkan dehidrasi, tujuan penelitian untuk mengetahui apakah ada hubungan Pengetahuan Ibu Hamil Dengan Kecemasan Dalam Menghadapi Hiperemesis Gravidarum Kehamilan Trimester I di RSUD Sultan Sulaiman Tahun 2020. Penelitian ini menggunakan jenis penelitian kuantitatif, dengan desain crosssectional, Desain penelitian ini menggunakan desain crosssectional, Populasi dalam penelitian adalah ibu hamil trimester pertama yang melakukan pemeriksaan kehamilan di RSUD Sultan Sulaiman Tahun 2020sebanyak 90 orang, sampel dengan mengunakan Acidental sampling yaitu dimana sampel yang didapat kan pada saat penelitia melakukan penelitian yaitu sebanyak 2 minggu, dengan teknik penelitian menggunakan uji Chi Kuadrat. Hasil penelitian Pengetahuan ibu hamil tentang hiperemesis gravidarum di RSUD Sultan Sulaiman mayoritas dalam kategori cukup sebanyak 16 orang $(53,3 \%)$, Kecemasan ibu hamil dalam menghadapi hiperemesis gravidarum kehamilan trimester I di RSUD Sultan Sulaiman mayoritas berada pada kategori kecemasan sedang sebanyak 13 orang $(43,3 \%)$. Kesimpulan Ada hubungan yang signifikan antara pengetahuan ibu hamil dengan kecemasan dalam menghadapi hiperemesis gravidarum kehamilan trimester I di RSUD Sultan Sulaiman Tahun 2020. Disarankan Bagi tempat penelitian, perlunya mengadakan penyuluhan kesehatan kehamilan agar tingkat kecemasan pada ibu hamil dalam menghadapi hyperemesis gravidarum pada kehamilan trimester I dapat diturunkan.
\end{abstract}

\section{Koresponden Penulis:}

Zuidah,

Program Studi Keperawatan, Universitas Haji Sumatera Utara,

Jl. Rumah Sakit H., Medan Estate, Kec. Percut Sei Tuan, Kabupaten Deli Serdang, Sumatera Utara 20371.

Email: zuidah66@gmail.com

\section{PENDAHUluan}

Kehamilan merupakan episode dramatis terhadap kondisi biologis dan adaptasi seseorang wanita yang pernah mengalami kehamilan. Sebagian besar wanita menganggap bahwa kehamilan adalah peristiwa kodrati yang harus dilalui, tetapi sebagian menganggap sebagai peristiwa khusus yang menentukan kehidupan selanjutnya, karena perubahan ini adalah proses yang alami (fisiologis) maka sudah sewajarnya bila diperlakukan dengan wajar tanpa interpensi dan manipulasi dari luar. (Saifuddin, 2018).

Sekitar 50\% wanita hamil mengalami mual-mual, dan beberapa sampai muntah-muntah. Keluhan ini terjadi dalam 12 minggu pertama kehamilan, biasanya menghilang pada akhir waktu tersebut. Penyebabnya hampir dapat dipastikan karena kepekaan terhadap hormone kehamilan. Tetapi, akan berlebihan jika calon ibu terlalu cemas atau mengalami tekanan emosional. Kebanyakan mual-mual terjadi pagi hari, sehingga dinamakan pusing pagi, tetapi mungkin saja terjadi kapan pun. Mual-mual di pagi hari lebih umum daripada disaat yang lain, karena perut mengandung kumpulan asam gastrik yang diendapkan semalaman. 
Kebanyakan wanita dapat mengatasi mual-mual dengan cara sederhana. Komposisi makanan seharusnya disesuaikan dengan tidak memakan yang mengandung lemak. Makanan dengan karbohidrat rendah sebaiknya dimakan lebih sering. Ini terdiri atas biscuit dan teh. Setelah itu, makanan kecil dimakan setiap 3 jam sampai waktu tidur. Beberapa wanita lebih suka menghindari minum diantara jadwal makannya dan minum cairan, baik sari buah manis, teh dan susu dari air soda pada saat yang lain (Llewellyn Derek, 2017).

Kecemasan pada kehamilan, selain terjadi perubahan fisiologi, psikologis juga memegang peranan yang tidak kalah penting dalam timbulnya mual muntah (Prawirohardjo, 2018). Perubahan kondisi fisik dan emosional yang kompleks memerlukan adaptasi terhadap penyesuaian pola hidup dengan proses kehamilan yang terjadi. Konflik antara keinginan, penolakan, kebanggaan yang ditimbulkan dari norma-norma sosial kultur dan persoalan dalam kehamilan itu sendiri dapat merupakan pencetus berbagai reaksi psikologis, mulai dari reaksi emosional ringan hingga ke tingkat gangguan jiwa yang berat (Saifuddin, 2018).

Salah satu perubahan fisiologis pada ibu hamil merasakan Kecemasan yang terjadi pada masa kehamilan terjadi perubahan pada system pencernaan, selama masa hamil nafsu makan berkurang, sekresi usus berkurang, fungsi hati berubah dan absrobsi nutrisi meningkat. Aktivitas peristaltik (motilitas) menurun, akibatnya bising usus berkurang sehingga terjadi stagnasi isi lumen usus disampaikan ke cortek serebri kemudian dipersepsikan sebagai rasa penuh di perut sehingga berdampak pada rasa mual dan muntah serta tidak nafsu makan umum terjadi, pada trimester 1 sering terjadi penurunan nafsu makan akibat nausea (mual) dan atau vomitus (muntah) yang merupakan akibat perubahan saluran cerna dan peningkatan kadar progesteron, estrogen dan human chorionic gonadotropin (hCG) dapat menjadi faktor pencetus mual dan muntah. Peningkatan hormone progesteron menyebabkan otot polos pada sistem gastrointestinal mengalami relaksasi sehingga motilitas lambung menurun dan pengosongan lambung melambat. Refluks esofagus, penurunan motilitas lambung dan penurunan sekresi asam hidroklorid juga berkontribusi terhadap terjadinya mual dan muntah hal ini diperberat dengan adanya penyebab lain berkaitan dengan faktor psikologis, spiritual, lingkungan dan sosiokultural (Runiari, 2018)

Hiperemesis gravidarum yang merupakan komplikasi pada ibu hamil muda bila terjadi terus menerus dapat menyebabkan dehidrasi, ketidakseimbangan elektrolit disertai alkalosis hipokloremik, serta dapat mengakibatkan cadangan karbohidrat dan lemak habis terpakai untuk keperluan energi. Oksidasi lemak yang tidak sempurna menyebabkan ketosis dengan tertimbunnya asam aseto-asetik, asam hidroksi butirik dan aseton dalam darah. Kekurangan asupan makanan dan kehilangan cairan karena muntah menyebabkan dehidrasi, sehingga cairan ekstraseluler dan plasma berkurang. Natrium dan klorida dalam darah maupun urine turun, selain itu dehidrasi menyebabkan hemokonsentrasi sehingga menyebabkan aliran darah ke jaringan berkurang. Kekurangan kalium sebagai akibat dari muntah dan bertambahnya ekskresi lewat ginjal berakibat frekuensi muntah bertambah banyak sehingga dapat merusak hati (Runiari, 2018).

Keadaan dehidrasi dan intake yang kurang mengakibatkan penurunan berat badan yang terjadi bervariasi tergantung durasi dan beratnya penyakit. Percernaan serta absorpsi karbohidrat dan nutrisi lain yang tidak adekuat mengakibatkan tubuh membakar lemak untuk mempertahankan panas dalam tubuh, jika tidak ada karbohidrat maka lemak digunakan untuk menghasilkan energi akibatnya beberapa hasil pembakaran dari metabolisme lemak terdapat dalam darah dan urine (terdapat atau kelebihan keton dalamurine) (Runiari, 2018).

Salah satu komplikasi akibat kehamilan adalah hyperemesis gravidarum yang merupakan mual dan muntah yang berlebihan sehingga pekerjaan sehari-hari terganggu dan keadaan umum menjadi buruk. Mual dan muntah merupakan gangguan yang paling sering di jumpai pada kehamilan trimester 1, sekitar 60-80\% primigravida dan 40-60\% multigravida ini mengalami mual dan muntah namun gejala ini menjadi lebih berat hanya pada 1 dari 1.000 kehamilan (Mansjor, 2017). Rasa mual dan muntah cenderung lebih parah terjadi pada kehamilan pertama secara emosi ibu yang baru pertama kali hamil cenderung lebih peka terhadap kecemasan dan ketakutanyang akhirnya mengganggu lambung, primigravida beresiko mengalami mual dan muntah sebanyak 53,5\% pada multigravida $36,4 \%$ dan grande multipara 11,1\% (Manuaba, 2017) 
Faktor yang dapat diharapkan memberikan kontribusi dalam kehamilan adalah dukungan dari keluarga. WHO menulis bahwa keluarga sebagai "Primary Social Agent" dalam promosi kesehatan atau penelitian kesehatan sangat dipengaruhi prilaku kesehatan dan pendekatan melalui keluarga. Hal ini merupakan cara yang paling efektif dan efisien. (Soetiono, 2018).

Sedangkan faktor yang mempengaruhi emesis gravidarum itu sendiri adalah factor predisposisi yang sering dikemukakan adalah primigravida, molahidatidosa dan kehamilan ganda, faktor masuknya vili khorialis, alergi, psiko logik dan juga sosial ekonomi (Prawirohardjo, 2017)

Hasil penelitian yang dilakukan oleh Esti Hitatami pada tahun 2017 tentang gambaran pengetahuan ibu hamil trimester 1 tentang hyperemesis gravidarum di poliklinik kandungan Rumah Sakit Immanuel Bandung menunjukan bahwa 80,39 \% ibu memiliki pengetahuan yang baik tentang komplikasi hyperemesis gravidarum. Penelitian yang dilakukan oleh Desti Yulanda pada tahun 2017 tentang hubungan antara pengetahuan ibu hamil tentang tanda bahaya kehamilan dengan sikap deteksi dini komplikasi kehamilan di Puskesmas Kartasurya didapatkan 70\% ibu hamil memiliki pengetahuan cukup dalam deteksi dini komplikasi kehamilan (Desti, 2017).

Studi pendahuluan yang di lakukan peneliti di RSUD Sultan Sulaiman Tahun 2020 pada bulan Juli 2020 terdapat 15 ibu hamil yang memeriksakan kehamilannya 7 orang diantaranya mengaku mengalami mual muntah yang berlebihan (hyperemesis gravidarum). Tujuh orang ibu hamil tersebut terdiri dari 4 orang ibu yang pertama kali hamil, 2 orang ibu dengan hamil anak kedua dan 1 orang ibu hamil anak ketiga. Setelah dilakukan wawancara terhadap 7 orang ibu hamil tersebut mengenai mual muntah berlebihan yang dilakukan oleh ibu-ibu hamil tersebut adalah dengan minum air putih, menghindari makanan yang berbau amis dan menghentikan aktivitas yang dikerjakannya gejala mual dan muntah berlebihan tersebut sedikit berkurang, namun jika sudah mengganggu aktivitas bahkan sampai tidak bisa beraktivitas karena lemah, disertai pusing, mereka datang ke klinik bidan atau Puskesmas memeriksakan kondisinya dan mereka akan di beri obat antimuntah, setelah obat antimuntah tersebut habis dan kejadian mual muntah berlebihan tersebut terulang kembali, mereka akan kembali memeriksakan kondisinya dan akan di beri obat antimuntah. Ibu hamil tersebut mengatakan tidak mengerti bagaimana cara mencegah kejadian mual muntah berlebihan dirumah selain datang ke klinik dan meminum obat antimuntah yang diberikan oleh bidan, pada saat melakukan studi pendahuluan peneliti melihat sebanyak 20 orang ibu hamil memeriksakan kehamilan tanpa di dampingi suaminya. Data tersebut menunjukan pentingnya penanggulangan dini terjadinya hiperemesis gravidarum sehingga ibu tidak mengalami dehidrasi, jika dibiarkan terus menerus akan mengakibatkan dampak terhadap derajat kesehatan ibu dan tingkat kematian ibu. Berdasarkan latar belakang diatas maka melakukan penelitian tentang "Hubungan Pengetahuan Ibu Hamil Dengan Kecemasan Dalam Menghadapi Hiperemesis Gravidarum Kehamilan Trimester I di RSUD Sultan Sulaiman Tahun 2020".

\section{METODE PENELITIAN}

Penelitian ini dilakukan di RSUD Sultan Sulaiman yang beralamat di Jl Jalan negara km 58 nomor 315 sei rampah kab serdang bedagai. Rumah Sakit Umum Daerah Sultan Sulaiman merupakan rumah sakit kelas $\mathrm{C}$ dengan jumlah tenaga medis dokter umum 13 orang, dokter gigi 3 orang, dokter spesialis 14 orang. Jumlah tenaga perawat sebanyak 74 orang dan kebidanan 22 orang serta kefarmasian 8 orang. Pelayanan RSUD Sultan Sulaiman meliputi klinik 24 jam, klinik umum, klinik gigi, klinik spesialis, laboratorium, radiologi, ruang bayi (perinatologi), kamar bedah, pengelola limbah cairan dan ambulance 24 jam.

RSUD kedepan berupaya untuk mencapai Akreditasi Versi 2012/ Joint Commition International (JCI) dan terus berusaha untuk berkembang lagi. Baik saran prasarana, sumber daya manusia, hingga acuan pelayanan kesehatan yang ada. Dan saat ini sedang dilaksanakan pembangunan dengan sinergi dan bertahap gedung baru RSUD Sultan Sulaiman dengan jumlah tempat tidur yang $\geq 200$ unit guna memenuhi standart Sarana dan layanan Rumah Sakit Kelas B.

\section{HASIL DAN PEMBAHASAN}

\subsection{Hasil}


Berdasarkan hasil penelitian di RSUD Sultan Sulaiman Tahun 2020 diketahui data karakteristik responden berdasarkan umur, pendidikan, pekerjaan dan paritas yang diperoleh dari 26 responden. Hasil data karakteristik responden disajikan dalam bentuk tabel dibawah ini :

Tabel 1. Data Karakteristik Responden di RSUD Sultan Sulaiman Tahun 2020

\begin{tabular}{|c|c|c|c|}
\hline No & Data Demografi & Frekuensi & Presentase (\%) \\
\hline \multirow[t]{5}{*}{1} & Umur & & \\
\hline & $<25$ tahun & 5 & 16,7 \\
\hline & 25-35 tahun & 23 & 76,7 \\
\hline & $>35$ tahun & 2 & 6,6 \\
\hline & Jumlah & 30 & 100 \\
\hline \multirow[t]{5}{*}{2} & Pendidikan & & \\
\hline & SMP & 11 & 36,7 \\
\hline & SMA & 14 & 46,7 \\
\hline & Perguruan Tinggi & 5 & 16,6 \\
\hline & Jumlah & 30 & 100 \\
\hline \multirow[t]{6}{*}{3} & Pekerjaan & & \\
\hline & IRT & 17 & 56,7 \\
\hline & Wiraswasta & 8 & 26,7 \\
\hline & Pegawai Swasta & 3 & 10,0 \\
\hline & PNS & 2 & 6,7 \\
\hline & Jumlah & 30 & 100 \\
\hline \multirow[t]{3}{*}{4} & Paritas & & \\
\hline & $<2$ anak & 11 & 36,7 \\
\hline & $\geq 2$ anak & 19 & 63,3 \\
\hline & Jumlah & 30 & 100 \\
\hline
\end{tabular}

Dari tabel 1 di atas karakteristik responden berdasarkan umur mayoritas 25-35 tahun sebanyak 23 orang $(76,7 \%)$ dengan tingkat pendidikan mayoritas SMA sebanyak 14 orang $(46,7 \%)$ dan berdasarkan pekerjaan mayoritas sebagai IRT sebanyak 17 orang (56,7\%). Selanjutnya dilihat dari paritas, mayoritas responden memiliki anak $\geq 2$ anak yaitu sebanyak 19 responden $(63,3 \%)$.

Distribusi frekuensi data pengetahuan ibu hamil tentang hiperemesis gravidarum di RSUD Sultan Sulaiman Tahun 2020 dapat dilihat pada tabel 2 berikut:

Tabel 2. Distribusi Frekuensi Data Pengetahuan Ibu Hamil Tentang Hiperemesis Gravidarum di RSUD Sultan Sulaiman Tahun 2020

\begin{tabular}{cccc}
\hline No & Pengetahuan Ibu Hamil & Frekuensi & Persentase (\%) \\
\hline 1 & Baik & 9 & 30,0 \\
2 & Cukup & 16 & 53,3 \\
3 & Kurang & 5 & 16,7 \\
\hline & Jumlah & 30 & 100 \\
\hline
\end{tabular}

Berdasarkan tabel 2 di atas diketahui bahwa pengetahuan ibu hamil tentang hiperemesis gravidarum di RSUD Sultan Sulaiman mayoritas dalam kategori cukup sebanyak 16 orang $(53,3 \%)$.

Distribusi frekuensi kecemasan ibu hamil dalam menghadapi hiperemesis gravidarum kehamilan trimester I di RSUD Sultan Sulaiman Tahun 2020 dapat dilihat pada tabel 3 berikut:

Tabel 3. Distribusi Frekuensi Kecemasan Dalam Menghadapi Hiperemesis Gravidarum Kehamilan Trimester I di RSUD Sultan Sulaiman Tahun 2020

\begin{tabular}{cccc}
\hline No & Kecemasan Ibu Hamil & Frekuensi & Persentase (\%) \\
\hline 1 & Tidak ada Kecemasan & 0 & 0,0 \\
2 & Kecemasan Ringan & 10 & 33,3 \\
3 & Kecemasan Sedang & 13 & 43,3 \\
4 & Kecemasan Berat & 7 & 23,3 \\
\hline & Jumlah & 30 & 100 \\
\hline
\end{tabular}

Berdasarkan tabel 3 di atas diketahui bahwa kecemasan ibu hamil dalam menghadapi hiperemesis gravidarum kehamilan trimester I di RSUD Sultan Sulaiman mayoritas berada pada kategori kecemasan sedang sebanyak 13 orang $(43,3 \%)$.

\section{Analisis Bivariat}


Hubungan Pengetahuan Ibu Hamil Dengan Kecemasan Dalam Menghadapi Hiperemesis Gravidarum Kehamilan Trimester I di RSUD Sultan Sulaiman Tahun 2020

Data analisis hubungan pengetahuan ibu hamil dengan kecemasan dalam menghadapi hiperemesis gravidarum kehamilan trimester I di RSUD Sultan Sulaiman Tahun 2020 dapat dilihat pada tabel 4 berikut :

Tabel 4. Tabulasi Silang Hubungan Pengetahuan Ibu Hamil Dengan Kecemasan Dalam Menghadapi Hiperemesis Gravidarum Kehamilan Trimester I di RSUD Sultan Sulaiman Tahun 2020

\begin{tabular}{|c|c|c|c|c|c|c|c|c|c|}
\hline \multirow{3}{*}{$\begin{array}{c}\text { Pengetahuan } \\
\text { Ibu }\end{array}$} & \multicolumn{6}{|c|}{$\begin{array}{c}\text { Kecemasan Menghadapi Hiperemesis } \\
\text { Gravidarum }\end{array}$} & \multirow{2}{*}{\multicolumn{2}{|c|}{ Total }} & \multirow[t]{3}{*}{$p$-value } \\
\hline & \multicolumn{2}{|c|}{ Ringan } & \multicolumn{2}{|c|}{ Sedang } & \multicolumn{2}{|c|}{ Berat } & & & \\
\hline & f & $\%$ & $\mathbf{f}$ & $\%$ & $\mathbf{f}$ & $\%$ & f & $\%$ & \\
\hline Baik & 7 & 23,3 & 2 & 6,7 & 0 & 0,0 & 9 & 30,0 & \multirow{4}{*}{0,004} \\
\hline Cukup & 2 & 6,7 & 10 & 33,3 & 4 & 13,3 & 16 & 53,3 & \\
\hline Kurang & 1 & 3,3 & 1 & 3,3 & 3 & 10,0 & 5 & 16,7 & \\
\hline Total & 10 & 33,3 & 13 & 43,3 & 7 & 23,3 & 30 & 100,0 & \\
\hline
\end{tabular}

Berdasarkan data pada tabel 4 di atas dapat diketahui bahwa 9 responden yang memiliki pengetahuan baik mayoritas mengalami kecemasan ringan menghadapi hiperemesis gravidarum yaitu 7 orang $(23,3 \%)$. Selanjutnya dari 16 responden yang memiliki pengetahuan cukup mayoritas mengalami kecemasan sedang menghadapi hiperemesis gravidarum yaitu 10 orang $(33,3 \%)$. Sedangkan dari 5 responden yang memiliki pengetahuan kurang mayoritas mengalami kecemasan berat menghadapi hiperemesis gravidarum yaitu 3 orang $(10,0 \%)$.

Hasil pengolahan data dengan chi square diketahui bahwa nilai p-value signifikan yaitu 0,004 p-value < 0,05 maka Ho ditolak dan Ha diterima sehingga pada penelitian ini terdapat hubungan yang signifikan antara pengetahuan ibu hamil dengan kecemasan dalam menghadapi hiperemesis gravidarum kehamilan trimester I di RSUD Sultan Sulaiman Tahun 2020. Hal ini menunjukkan bahwa semakin baik pengetahuan ibu tentang hyperemesis gravidarum, maka kecemasan ibu menghadapi hiperemesis gravidarum kehamilan trimester I akan semakin ringan.

\subsection{Pembahasan}

Berdasarkan hasil penelitian dapat diketahui bahwa pengetahuan responden tentang pengetahuan Ibu Hamil Tentang Hiperemesis Gravidarum di RSUD Sultan Sulaiman mayoritas dalam kategori cukup sebanyak 16 orang $(53,3 \%)$.

Hasil penelitian ini sesuai dengan penelitian yang dilakukan oleh (Subinantaro, 2013), di BPS Sang Timur Klaten tentang Hiperemesis Gravidarum dengan hasil mayoritas ibu berpengetahuan cukup yaitu sebanyak 25 orang. Jadi tingkat pengetahuan ibu hamil trimester 1 tentang Hiperemesis Gravidarum di BPS Sang Timur Klaten kebanyakan berpengetahuan cukup baik.

Dari hasil penelitian tentang pengetahuan responden tentang pengetahuan Ibu Hamil Tentang Hiperemesis Gravidarum di RSUD Sulaiman mayoritas berpengetahuan cukup. Dapat dipengaruhi oleh beberapa faktor yaitu faktor pendidikan dimana pendidikan akan mempengaruhi proses pertumbuhan, dan perkembangan seseorang terhadap informasi yang diterimanya. Oleh karena itu semakin tingginya pendidikan seseorang maka semakin baik pula pengetahuannya.

Dari hasil penelitian berdasarkan pendidikan responden mayoritas pendidikanya menengah yaitu 14 orang $(46,7 \%)$ dan pendidikan rendah sebanyak 11 orang $(36,7 \%)$ dengan demikian pengetahuan responden tentang Hiperemesis Gravidarum cukup dapat disebabkan oleh rendahnya pendidikan responden sehingga pengetahuannya menjadi cukup.

Selain pendidikan, usia juga dapat mempengaruhi pengetahuan seseorang karena semakin bertambah usia akan semakin berkembang pengetahuannya. Tetapi menjelang usia lanjut kemampuan penerimaan atau mengingat suatu pengetahuan akan berkurang. Dari hasil penelitian usia responden kategori umur dewasa 25-35 tahun adalah 23 orang $(76,7 \%)$. Seharusnya seseorang bisa berubah tetapi dari penelitian di usia dewasa malah pengetahuan responden semakin berkurang mungkin dikarenakan kurangnya informasi yang diperoleh responden tentang Hiperemesis Gravidarum.

Asumsi Penelitan Berdasarkan hasil penelitian dapat diketahui bahwa pengetahuan responden tentang pengetahuan Ibu Hamil Tentang Hiperemesis Gravidarum di RSUD Sultan 
Sulaiman mayoritas dalam kategori cukup Dapat dipengaruhi oleh beberapa faktor yaitu faktor pendidikan dimana pendidikan akan mempengaruhi proses pertumbuhan, dan perkembangan seseorang terhadap informasi yang diterimanya. Oleh karena itu semakin tingginya pendidikan seseorang maka semakin baik pula pengetahuannya

\section{Kecemasan Dalam Menghadapi Hiperemesis Gravidarum Kehamilan Trimester I di RSUD} Sultan Sulaiman Tahun 2020

Berdasarkan tabel 2 di atas diketahui bahwa kecemasan ibu hamil dalam menghadapi hiperemesis gravidarum kehamilan trimester I di RSUD Sultan Sulaiman mayoritas berada pada kategori kecemasan sedang sebanyak 13 orang $(43,3 \%)$.

Penelitian ini sejalan dengan penelitian yang dilakukan oleh Yessi (2012) yang didapatkan bahwa lebih dari separoh responden mengalami tingkat kecemasan sedang yaitu sebanyak 30 responden $(58,8 \%)$.

Tingkat kecemasan yang dirasakan oleh ibu hamil maka akan semakin tinggi pula peluang untuk mengalami hiperemesis gravidarum, karena kecemasan yang dirasakan ibu hamil tersebut akan memperburuk keadaan mual dan muntah yang dirasakannya sehingga akan mengalami mual muntah yang lebih berat lagi, hal tersebut akan mempengaruhi keadaan umum dan mengganggu aktifitas sehari-hari selain itu juga akan menganggu asupan nutrisi ibu hamil tersebut. Faktor psikologis seperti kecemasan sangat terlibat dalam etiologi hiperemesis gravidarum dan tidak hanya mempengaruhi durasi keparahan gejala namun juga mempengaruhi resistensi dan keberhasilan penatalaksanaannya.

Berdasarkan kesimpulan peneliti bahwa dari hasil penelitian ini peneliti menyimpulkan sebagian besar $(43,3 \%)$ ibu hamil yang mengalami kecemasan sedang. Menurut Gail (2006) kecemasan adalah kekhawatiran yang tidak jelas dan menyebar, yang berkaitan dengan perasaan tidak pasti, tidak berdaya, dan kondisi ini tidak memilki objek yang spesifik. Terjadinya kecemasan disebabkan oleh beberapa faktor seperti primigravida, mola hidtidosa dan kehamilan ganda yang dapat menimbulkan dugaan bahwa faktor hormon memegang peranan penting. Seperti yang didapatkan peneliti dalam karakteristik kehamilan responden bahwa sebagian besar responden sedang dalam kehamilan pertama. Faktor psikologik seperti keretakan dalam suatu rumah tangga, kehilangan pekerjaan, dan faktor hormon estrogen yang menyebabkan terjadinya peningkatan asam lambung yang memicu terjadinya kecemasan pada ibu hamil.

\section{Hubungan Pengetahuan Ibu Hamil Dengan Kecemasan Dalam Menghadapi Hiperemesis Gravidarum Kehamilan Trimester I di RSUD Sultan Sulaiman Tahun 2020}

Berdasarkan data pada tabel 4 di atas dapat diketahui bahwa 9 responden yang memiliki pengetahuan baik mayoritas mengalami kecemasan ringan menghadapi hiperemesis gravidarum yaitu 7 orang $(23,3 \%)$. Selanjutnya dari 16 responden yang memiliki pengetahuan cukup mayoritas mengalami kecemasan sedang menghadapi hiperemesis gravidarum yaitu 10 orang $(33,3 \%)$. Sedangkan dari 5 responden yang memiliki pengetahuan kurang mayoritas mengalami kecemasan berat menghadapi hiperemesis gravidarum yaitu 3 orang $(10,0 \%)$.

Hasil pengolahan data dengan chi square diketahui bahwa nilai p-value signifikan yaitu 0,004 p-value < 0,05 maka Ho ditolak dan Ha diterima sehingga pada penelitian ini terdapat hubungan yang signifikan antara pengetahuan ibu hamil dengan kecemasan dalam menghadapi hiperemesis gravidarum kehamilan trimester I di RSUD Sultan Sulaiman Tahun 2020. Hal ini menunjukkan bahwa semakin baik pengetahuan ibu tentang hyperemesis gravidarum, maka kecemasan ibu menghadapi hiperemesis gravidarum kehamilan trimester I akan semakin ringan.

Hasil penelitian ini sejalan dengan penelitian Oktaviani, dkk (2016) yang menyatakan ada hubungan antara pengetahuan dengan sikap ibu hamil dalam mencegah kejadian hiperemesis gravidarum di wilayah kerja Puskesmas Padalarang, dengan hasil uji chi-square diperoleh hasil $\mathrm{P}$ value $=0,049(\alpha<0,05)$. Informasi yang berkaitan dengan hiperemesis gravidarum sudah diberikan oleh tenaga kesehatan, baik melalui media cetak maupun berkonsultasi langsung. Informasi yang diterima oleh ibu hamil merupakan stimulus bagi ibu hamil untuk terjadinya perilaku.

Informasi yang adekuat menjadikan ibu hamil lebih waspada terhadap komplikasi hiperemesis gravidarum sekaligus menjadi acuan dalam menentukan sikap, terbentuknya sikap seseorang sangatlah ditentukan oleh pengetahuan atau informasi yang diterima, untuk mengetahui 
bahwa informasi tersebut dapat dipahami oleh ibu hamil dapat dilakukan dengan cara mengukur pengetahuan apakah ibu hamil tersebut sudah paham dengan cara mencegah kejadian hiperemesis gravidarum Notoadmodjo (2012) menjelaskan bahwa pengukuran pengetahuan dapat dilakukan dengan wawacara atau kuesioner yang menanyakan tentang isi materi yang akan diukur dari subyek penelitian atau responden, kedalaman pengetahuan yang kita ukur dapat kita sesuaikan dengan tingkatan-tingkatan, demikian juga dengan sikap menurut Notoadmodjo dalam Wawan (2015) pengukuran sikap dapat dilakukan langsung atau tidak langsung. Secara langsung dapat ditanyakan bagaimana pendapat atau pernyataan responden terhadap suatu objek secara tidak langsung dapat dilakukan dengan menggunakan pernyataan-pernyataan kemudian ditanyakan pendapat responden melalui kuesioner.

Hal tersebut di dukung oleh penelitian Hartaty (2012) tentang faktor-faktor yang berhubungan dengan kejadian hiperemesis gravidarum di Puskesmas Makale kab. Tana Toraja didapatkan bahwa ada hubungan antara pengetahuan dengan kejadian hiperemesis gravidarum didapatkan hasil $\mathrm{P}$ value $=0,006$, dengan demikian pengetahuan sangat berpengaruh terhadap pencegahan maupun kejadian hyperemesis gravidarum, menurut penelitian Hartaty tersebut pengetahuan ibu tentang kehamilan sangat berpengaruh terhadap kejadian hiperemesis gravidarum, dengan demikian semakin baik pengetahuan seseorang maka semakin baik pula cara mengatasi permasalahan terkait hiperemesis gravidarum demikian pula sebaliknya.

Asumsi Penelitian bahwa informasi yang adekuat menjadikan ibu hamil lebih waspada terhadap komplikasi hiperemesis gravidarum sekaligus menjadi acuan dalam menentukan sikap, terbentuknya sikap seseorang sangatlah ditentukan oleh pengetahuan atau informasi yang diterima, untuk mengetahui bahwa informasi tersebut dapat dipahami oleh ibu hamil dapat dilakukan dengan cara mengukur pengetahuan apakah ibu hamil tersebut sudah paham dengan cara mencegah kejadian hiperemesis gravidarum

\section{KESIMPULAN}

Pengetahuan ibu hamil tentang hiperemesis gravidarum di RSUD Sultan Sulaiman mayoritas dalam kategori cukup sebanyak 16 orang. Kecemasan ibu hamil dalam menghadapi hiperemesis gravidarum kehamilan trimester I di RSUD Sultan Sulaiman mayoritas berada pada kategori kecemasan sedang sebanyak 13 orang. Ada hubungan yang signifikan antara pengetahuan ibu hamil dengan kecemasan dalam menghadapi hiperemesis gravidarum kehamilan trimester I di RSUD Sultan Sulaiman Tahun 2020, dengan nilai $\mathrm{p}$ value $=0,004(\mathrm{p}<0,05)$. Hal ini berarti, semakin baik pengetahuan ibu tentang hyperemesis gravidarum, maka kecemasan ibu menghadapi hiperemesis gravidarum kehamilan trimester I akan semakin ringan.

\section{REFERENSI}

Abraham C. (2017), Psikologis Sosial Untuk Perawat, Jakarta : EGC

Damanik.S. (2017), Gamharan Dukungan Sosial Keluarga Dengan Terjadinya

Ernests Gravidarum Pada Kehamilan Trisemester I di Klinik Bersalin Hadijah Medan, Skripsi FKUSU. Medan.

Helen. (2018), Perawatan Maternis, Jakarta : EGC Hidayat. (2007), Metode

Penelitian Kebidanan Tehnik Analisa Data, Jakarta : Salemba Medika. Hulliana. (2016), Panduan Menjalani Kehamilan Sehat, Jakarta: Puspa Sari. Llewellyn Derek. (2017), Setiap wanitu, Delaptrasa Publishing.

Manuaba. (2017) limit Kebidanan Penyakit Kandungan dan Keluarga

Berencana Untuk Bidan, Jakarta: EGC. Mochtar. (2018). Sinopsis Obstetri, Jakarta: EGC

Musbikin. (2017), Panduan bagilbu Hamil dan melahirkan, Yogyakarta : Mitra Pustaka.

Nasrul. (2018), Dasar Keperawatan Kesehatan Masyarakat, Jakarta: EGC Nenderson. (2016), Konsep Kebidanan, Jakarta: EGC

Niven, (2017), Psikologis Kesehatan, Jakarta : EGC

Notoadmodjo. (2017), Metodologipenelitian kesehatan, Jakarta : Rineka Cipta Prawirohardjo. (2018), Pelayanan Kebidanan, Jakarta : Yayasan Bina Pustaka. Prawirohardjo. (2017), 
Pelayanan Kebidanan, Jakarta : Yayasan Bina Pustaka. Salmah. (2016) Asuhan Kebidanan Antenatal, Jakarta: EGC.

Setiono. (2018), Manusia Kesehatan dan Lingkungan, Bandung : KSJSM A.A 